\title{
Physical, Mineralogical, and Micromorphological Properities of Expansive Soil Treated at Different Temperature
}

\author{
Jian $\mathrm{Li}^{1}{ }^{1}$ Xiyong $\mathrm{Wu},{ }^{1}$ and Long $\mathrm{Hou}^{2}$ \\ ${ }^{1}$ Department of Geosciences and Environmental Engineering, Southwest Jiaotong University, Chengdu, Sichuan 610031, China \\ ${ }^{2}$ Wanzhou District Commission of Urban-Rural Development, Wanzhou, Chongqing 404000, China \\ Correspondence should be addressed to Jian Li; jlicivil@gmail.com
}

Received 11 February 2014; Accepted 6 April 2014; Published 28 April 2014

Academic Editor: Wen Zeng

Copyright (c) 2014 Jian Li et al. This is an open access article distributed under the Creative Commons Attribution License, which permits unrestricted use, distribution, and reproduction in any medium, provided the original work is properly cited.

\begin{abstract}
Different characterizations were carried out on unheated expansive soil and samples heated at different temperature. The samples are taken from the western outskirts of Nanning of Guangxi Province, China. In the present paper, the mineral and chemical composition and several essential physical parameters of unheated expansive soil are indicated by XRD and EDX analysis. Moreover, the structural transition and change of mechanical properties of samples heated in the range of room temperature to $140^{\circ} \mathrm{C}$ are proved by TG-DTA and SEM observation. The mean particle diameter, density, hydraulic behaviors, and bond strength also have been investigated. The results indicate that, along with the loss of free water, physical absorbed water, and chemically bound water, the microstructure experiences some obvious change. In addition, the particle size and density both will increase rapidly before $100^{\circ} \mathrm{C}$ and undertake a slow growth or decline when higher than $100^{\circ} \mathrm{C}$. The hydraulic behaviors and strength performance of unheated samples and the one heated at $100^{\circ} \mathrm{C}$ are given out as well. All these researches play fundamental role in the pollution prevention, modification, and engineering application of expansive soil.
\end{abstract}

\section{Introduction}

Expansive soils are soils that expand when water is added and shrink when it dries out. This continuous change in soil volume can cause homes and roads built on this soil to move unevenly and crack [1-3]. The special engineering properties of this soil are determined by the mineral phase and the chemical composition [4]. Therefore, researches on them are not only necessary for exploring the engineering properties of expensive soils and discussing the expansion mechanism but also indispensable as to the improvement and reinforcement of expansive soils and the discussion of new soil research techniques and methods $[5,6]$. During the application of expansive soils in the construction and employment of embankment, the peculiarity is influenced by both the nature of the denudation and deliquescence of expansive soils [7-9].

The variation of temperature has a critical influence on the engineering properties of soils [10-12]. The relevant researches were as early as the 20th century $\mathrm{AD}$, which were mainly focused on the soil evaporation and the invasion of precipitation $[2,13]$. On the other hand, more recent studies are primarily on how temperature affects the transformation and the further strength character of soil [14-16]. De Bruyn et al. have analyzed the results of triaxial test carried out at different temperature $\left(50^{\circ} \mathrm{C}, 80^{\circ} \mathrm{C}\right.$, and $\left.110^{\circ} \mathrm{C}\right)$ and different confining pressure $(2.1,3.1$, and $4.1 \mathrm{MPa})$, given the conclusion that the shear strength will increase with the rise of temperature $[17,18]$. However, researches on the influences of temperature on the change of physical and chemical properties including microstructure and hydraulic behaviors have been rarely reported before.

In this research, the expansive soil samples collected from the western outskirts of Hanzhong of Shanxi Province were characterized to analyse the chemical and mineral components. In addition, researches on the influence of temperature on the microstructure and physiochemical properties were also carried out. It is critically important to carry out this research project for the further pollution prevention, modification, and engineering application of expansive soil. 
TABLE 1: The mineral components and content of expansive soil (unit: \%).

\begin{tabular}{lccccc}
\hline Components & Montmorillonite & Illite & Kaolin & Quartz & Feldspar \\
\hline Content & 13 & 39 & 31 & 9 & 8 \\
\hline
\end{tabular}

\section{Materials and Experimental Procedure}

2.1. Materials. Expansive soils samples were collected 1.3 $1.5 \mathrm{~m}$ below earth surface from the western outskirts of Hanzhong of Shanxi Province, China. Approximately 3-5 Kg of soils samples was collected from six different sites. Samples were separated into several portions. Powder batches of about $500 \mathrm{~g}$ were kept or dried for $6 \mathrm{~h}$ at 20, 40, 60, 80, 90, 100, 120 , and $140^{\circ} \mathrm{C}$. Then the samples were removed from the furnace and cooled to room temperature in air. A powder batch of about $500 \mathrm{~g}$ was treated by air drying for the purpose of comparison experiment and TG-DT analysis.

2.2. Experimental Methods. X-ray diffraction (XRD) analysis was carried out on a Rigaku (Japan) D/MAX 2500C diffractometer using $\mathrm{GuK} \alpha$ radiation, voltage $40 \mathrm{kV}$, and current $200 \mathrm{~mA}$, equipped with a graphite monochromator in the diffracted beam. Crystalline phases were identified using the database of the International Center for Diffraction Data-JCPDS for inorganic substances. [JCPDS, International Centre for Diffraction Data, 1601 Park Line, Swarthmore, PA, 1987.]

Thermal analysis was performed on a Netzsch (Germany) STA 449 simultaneous analyzer. Thermogravimetric (TG) and differential thermal (DT) analysis were performed in the range of $20-140^{\circ} \mathrm{C}$ (stripping gas: dry $\mathrm{N}^{2}$, helium flow $=$ $100 \mathrm{~mL} / \mathrm{min}$, and heating rate: $5^{\circ} \mathrm{C} / \mathrm{min}$ ). Measurements were carried out in $0.3 \mathrm{~cm}^{3}$ volume alumina crucibles using $\alpha$ alumina as reference, analyzing $\approx 100 \mathrm{mg}$ of dry sample.

The volume frequency of particle diameter is characterized by a Winner2008A (Chinese) laser particle size analyzer, whose measuring range is $0.01-2000 \mu \mathrm{m}$. The density measurements were performed with a helium pycnometer (Micromeritics, Model 1305, USA). And the strength performance of expansive soil heated at different temperature is tested on a Trautwein DigiShearTM (Chinese) multifunctional direct shear test systems with the following testing condition: the shear rate is $0.03 \mathrm{~mm} /$ minute and the maximum shear displacement is $6.5 \mathrm{~mm}$.

SEM observation EDX analysis was performed on TESCAN VEGA II scanning electron microscope for the characterization of the micromorphology of expansive soil treated at different temperature.

\section{Components and Properties in Room Temperature}

3.1. Chemical and Mineral Components. The mineral component of expansive soil consists of clay mineral and detrital mineral. The ingredients of the clay mineral are mainly quartz, mica, feldspar, and a few of the calcites and gypsums, which are the major part of coarse grain [7]. Generally, due

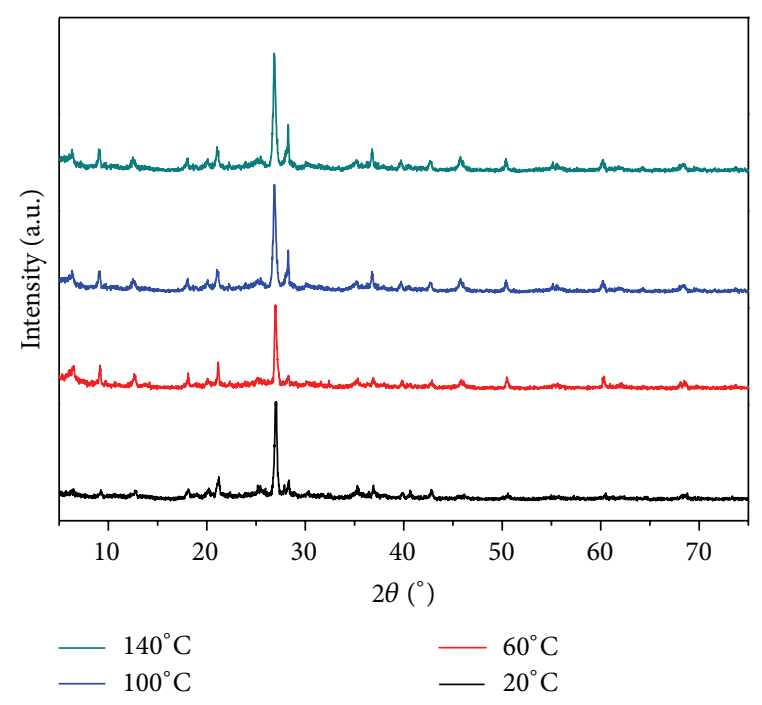

FIGURE 1: XRD patterns of untreated expansive soils $\left(20^{\circ} \mathrm{C}\right)$ and samples heated at $60^{\circ} \mathrm{C}, 100^{\circ} \mathrm{C}$, and $140^{\circ} \mathrm{C}$.

to the low content in expansive soil, the coarse grain has low effect on the swell-shrink property. On the contrary, the engineering properties of expansive soil are principally determined by the clay mineral, the fine grain, and especially the mineral like smectites.

The X-ray diffraction patterns of expansive soil samples are shown in Figure 1, which reflects that the main clay minerals are illite, montmorillonite, kaolinite, quartz, potash feldspar, and plagioclase according to the JCPDS cards. Moreover, the diffraction peaks have not waved and the intensity also has not changed with the variation of temperature $\left(20,60,100\right.$, and $\left.140^{\circ} \mathrm{C}\right)$, which indicates that the main mineral component has not changed. The mineral composition and the component can be given through the quantitative calculation of the intensity of the diffraction peak and full width at half maximum, which are shown in Table 1. It indicates that expansive soils from Hanzhong are mainly composed of illite and kaolin, which separately take $39 \%$ and $31 \%$ part of the total air drying sample, while the percentages of quartz and feldspar are lower than $10 \%$. It should be mentioned that the clay mineral component is not exactly close to the soil from other sites, which is because of the different depositional environment of mother rock and rate of decay during the soil-forming process.

In this project, EDX analysis was also employed to study the stability of expansive soil and the chemical composition and component which are shown in Table 2. From this table, it can be illustrated that, even though the result would vary with the EDX detection sites and the main components are $\mathrm{SiO}_{2}, \mathrm{Al}_{2} \mathrm{O}_{3}$, and $\mathrm{Fe}_{2} \mathrm{O}_{3}$, which three components accounting 
TABLE 2: The mineral components and content of expansive soil (unit: \%).

\begin{tabular}{lccccccc}
\hline Components & $\mathrm{Na}_{2} \mathrm{O}$ & $\mathrm{MgO}$ & $\mathrm{Al}_{2} \mathrm{O}_{3}$ & $\mathrm{SiO}_{2}$ & $\mathrm{~K}_{2} \mathrm{O}$ & $\mathrm{Fe}_{2} \mathrm{O}_{3}$ & $\mathrm{SiO}_{2} / \mathrm{Al}_{2} \mathrm{O}_{3}$ \\
\hline Content & 3.2 & 6.7 & 19.5 & 47.3 & 8.4 & 12.8 & 2.1 \\
\hline
\end{tabular}

TABLE 3: The physical parameters of expansive soil.

\begin{tabular}{|c|c|c|c|c|c|}
\hline Index & $\begin{array}{c}\text { Specific weight } \\
\gamma / \mathrm{kN} \cdot \mathrm{m}^{-3}\end{array}$ & $\begin{array}{c}\text { Liquid limit } \\
\omega_{L} / \%\end{array}$ & $\begin{array}{c}\text { Plastic limit } \\
\omega_{P} / \%\end{array}$ & $\begin{array}{l}\text { Plasticity index } \\
I_{P}\end{array}$ & $\begin{array}{c}\text { Free swell ratio } \\
\delta_{\mathrm{ef}} / \%\end{array}$ \\
\hline Soil & 19.7 & 37.9 & 17.3 & 20.6 & 54 \\
\hline
\end{tabular}

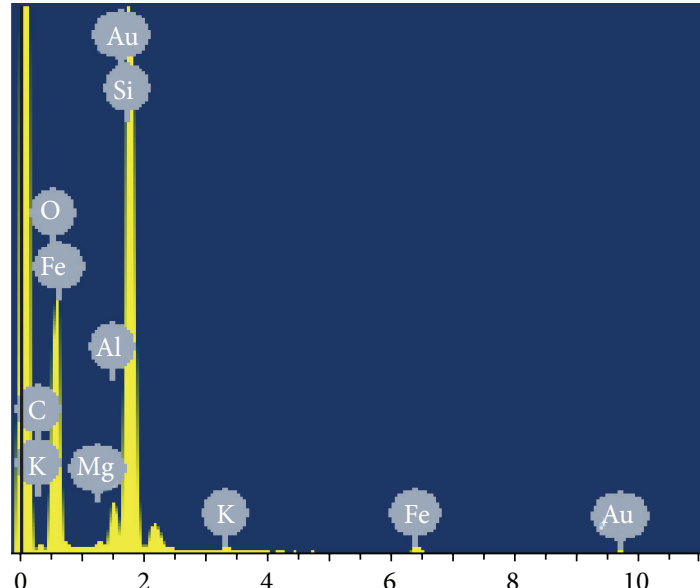

FIGURE 2: The result of expansive soil sample with EDX.

for around $80 \%$ of expansive soil. As a consequence, the enrichment of quartz mineral in course mineral and the enrichment of aluminum silicate clay minerals in fine mineral can be concluded.

Among the chemical compositions of colloidal particle of expansive soil, the molecular ratio of silicon aluminum is 3.94, which indicates that the major mineral composition is illite, corresponding to the identification result. The high components of vivacious alkali metals and alkaline-earth metals such as $\mathrm{K}, \mathrm{Na}, \mathrm{Ca}$, and $\mathrm{Mg}$ demonstrate the low degree of the weathering leaching and chemical weathering and that this soil can be further weathered when the climate, aqueous medium, and oxidoreduction environment are different. Consequently, the engineering properties would be worse for the hydrophilic enhancement. The EDX pattern is shown in Figure 2 where the existence of $\mathrm{Au}$ element is due to the spraying for SEM observation.

3.2. Physical Property. The sample soils belong to the mound hilly mudstone swell-shrinking soil area, the bed rock of which is lacustrine deposition mud and silty mud and the surface of which is soil from intense weathering and shows the structure of stratiform and color of greyish-green [19]. What is more, this soil is interbedded by silty mudstone and mudstone siltstone. That is the reason why strong expansive soils from Hanzhong are famous. The physical parameters

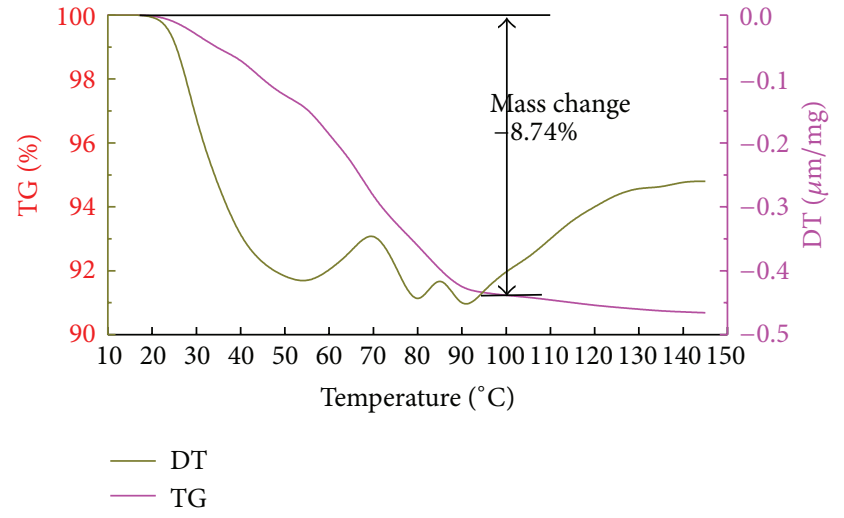

FIGURE 3: Thermogravimetric (TG) and differential thermal (DT) analysis diagram of heated expansive soil.

including specific weight, liquid limit, and plastic limit of expansive soil are given in Table 3.

Table 3 shows that the specific weight is $19.7 \mathrm{\gamma} / \mathrm{kN} \cdot \mathrm{m}^{-3}$, which is similar to that of soil from the north of Hubei, China [7], while the liquid limit and plastic limit are separately $37.9 \%$ and $17.3 \%$, in which the two can be used to identify the status of the soil and be further helpful for the application of expansive soil. In addition, the plasticity index is 20.6, which means that the expansive soil can have a high hydrophilic. Except for the parameters on the plasticity given before, another one is free swell ratio as large as 54\%, which can directly reflect the high expansibility of expansive soil.

\section{The Influence of Temperature}

4.1. TG-DT Analysis. The TG-DTA diagram (Figure 3) shows a continuous weight loss distributed in the range of $20-140^{\circ} \mathrm{C}$. The figure shows two main portions of mass loss as the rise of temperature. The first one is during the heating temperature interval of $20-100^{\circ} \mathrm{C}$ when the free water and some physically absorbed water are off. Before the heating temperature is up to $100^{\circ} \mathrm{C}$, the sample loses $8.74 \%$ of its total weight. The proportion of physically absorbed water is small. Combined with Table 3 of physical properties, it can be known that the lost water is mainly from the free water. Therefore, the moisture content of expansive soil is around $8 \%$, which is lower than the liquid limit and the airing treated expansive soil is in the semisolid state. 


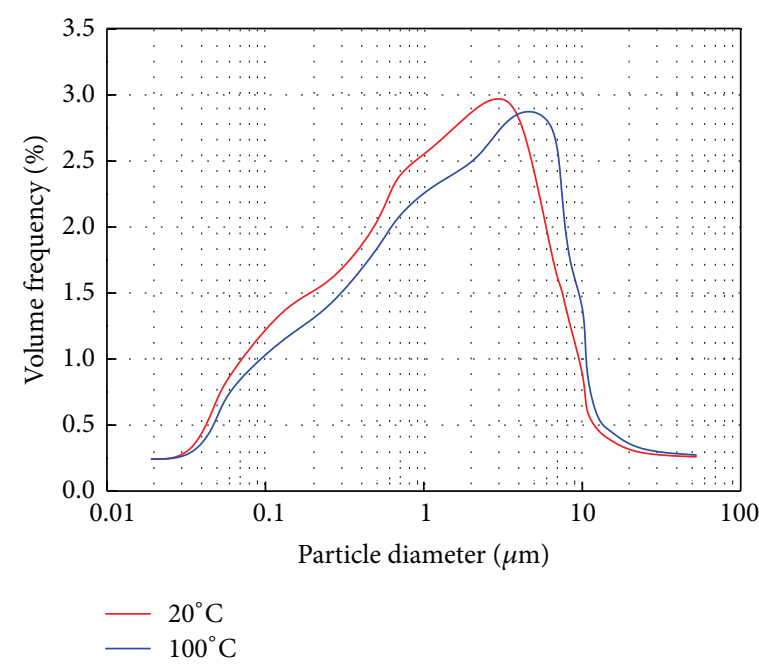

(a)

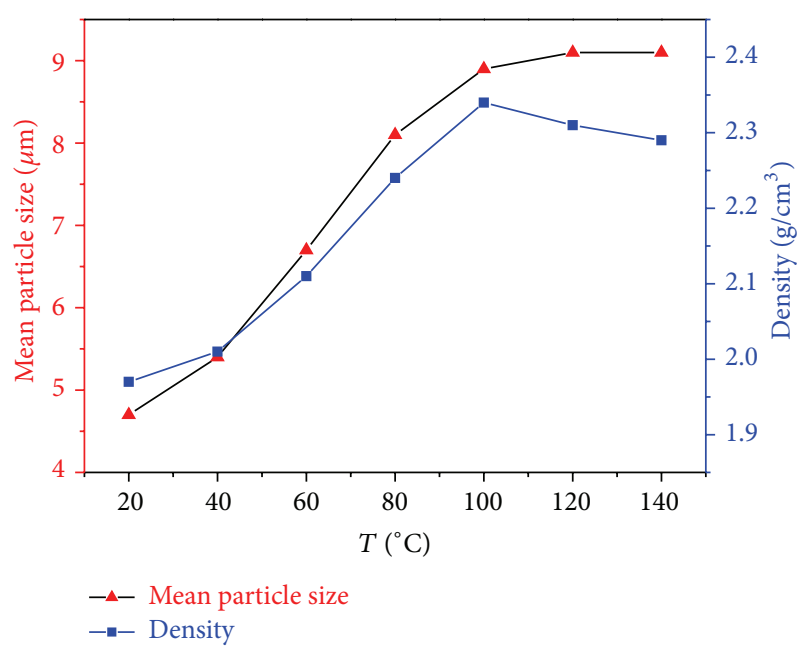

(b)

Figure 4: (a) Particle size distribution of expansive soil at room temperature $\left(20^{\circ} \mathrm{C}\right)$ and heated at $100^{\circ} \mathrm{C}$. (b) Mean particle size and density at different heated temperature.

Then the mass of the sample undertakes a slight decline in the range of $100 \sim 140^{\circ} \mathrm{C}$ with a mass change of $1.18 \%$. This portion of mass decrement is due to the drain of part of physically absorbed water and chemically bound water. For the existence of $\mathrm{Al}(\mathrm{OH})_{3}$ and carbonate terrane in the clay mineral of expansive soil, the lost chemically bound water is mainly from the release of $\mathrm{H}_{2} \mathrm{O}$ and $\mathrm{CO}_{2}$ separately from the decomposition of $\mathrm{Al}(\mathrm{OH})_{3}$ and carbonate terrane. The comparison of the different parts of loss illustrates that the loss of expansive soil during the heat treatment is occurring mainly before $100^{\circ} \mathrm{C}$ as a consequence of the elimination of free water and physical absorbed water.

4.2. Particle Size and Density. The physical properties such as particle size, density, and strength change with the increase of the heated temperature of expansive soil. These properties of expansive soil can significantly influence the occurring possibility of landslide and the settlement of the foundation [20]. The particles size distribution of the unheated expansive soil $\left(20^{\circ} \mathrm{C}\right)$ and expansive soil heated at $100^{\circ} \mathrm{C}$ is shown in Figure 4(a). It can be seen that the unheated expansive soil particles are mostly in the range of $0.096-13.5 \mu \mathrm{m}$ with a mean value of $4.67 \mu \mathrm{m}$. Compared with the unheated expansive soil, the heat treated one has a relatively large particle diameter. The particle diameter of expansive soil heated at $100^{\circ} \mathrm{C}$ is between $0.052 \mu \mathrm{m}$ and $11.7 \mu \mathrm{m}$ with an average value of $8.81 \mu \mathrm{m}$. It is believed that the rise of particle size is due to the dehydration consolidation during the evaporation process.

With the change of heated temperature from $20^{\circ} \mathrm{C}$ to $140^{\circ} \mathrm{C}$, which can indicate from Figure $4(\mathrm{~b})$ that the average particle diameter of expansive soil rise from $4.67 \mu \mathrm{m}$ at $20^{\circ} \mathrm{C}$ to $9.03 \mu \mathrm{m}$ at $140^{\circ} \mathrm{C}$, the temperature from $20^{\circ} \mathrm{C}$ to $100^{\circ} \mathrm{C}$ saw the rapid increase of mean particle size from $4.67 \mu \mathrm{m}$ to $8.81 \mu \mathrm{m}$, followed by a slow rise to $9.03 \mu \mathrm{m}$ at $140^{\circ} \mathrm{C}$.
With a similar increase tendency of mean particle size, the density of expansive soil also sharply grows from $1.94 \mathrm{~g} / \mathrm{cm}^{3}$ to $2.28 \mathrm{~g} / \mathrm{cm}^{3}$ As the temperature is increasing from $20^{\circ} \mathrm{C}$ to $100^{\circ} \mathrm{C}$, the density of expansive soil experiences a rapid increase to the value of 2.35 . And then the density declines slightly from $2.35 \mathrm{~g} / \mathrm{cm}^{3}$ at $100^{\circ} \mathrm{C}$ to $2.28 \mathrm{~g} / \mathrm{cm}^{3}$ at $140^{\circ} \mathrm{C}$. As well as the particle size, the density also rises up because of the dehydration consolidation. As to the large growth rate before $100^{\circ} \mathrm{C}$, it comes from the high water content and fast free water loss during the heat treatment. While the loss of physically absorbed water and chemically bonded water will exert a weak influence on both the density and the particle size. But the decomposition of $\mathrm{Al}(\mathrm{OH})_{3}$ and carbonate terrane can lead to the creak and transformation of some clay mineral particle, which will further make the density at a low value.

4.3. SEM Characterization. The microstructure and the morphology play important role in the status of expansive soil and influence the expanding and shrinking behavior of expansive soil [21]. For the purpose of further comprehending the phase change progress of expansive soil during heat treatment, untreated expansive soil and samples heated at $60^{\circ} \mathrm{C}, 100^{\circ} \mathrm{C}$, and $140^{\circ} \mathrm{C}$ are dispersed in anhydrous alcohol and grinded by ultrasonic vibration for the same time $(4 \mathrm{~h})$. Then the samples were observed by scanning electron microscope to obtain the micromorphology maps of these samples. The SEM images of unheated expansive soil and heat treated one are shown in Figure 5.

From Figure 5(a) it can be known that the microscopic structure of untreated expansive soil is relatively loose, with high porosity and small particle size. On the contrary, the diagrams of expansive soil heated at a series of temperatures (Figures 5(b)-5(d)) indicate that the heat treatment can improve the value of particle diameter and make the particles 


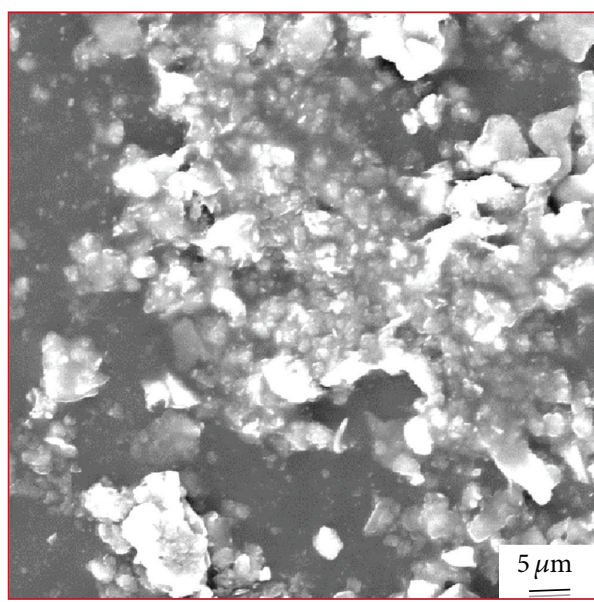

(a)

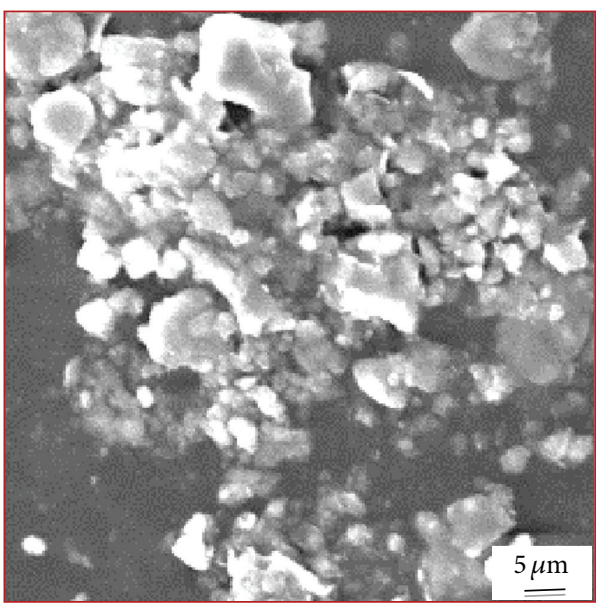

(c)

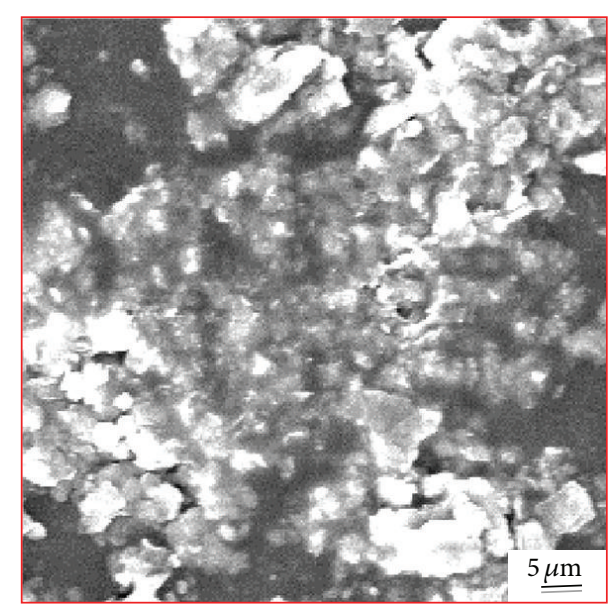

(b)

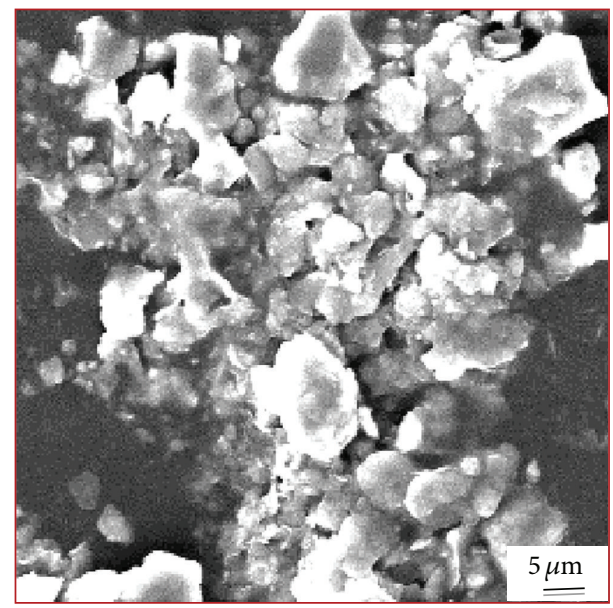

(d)

Figure 5: The SEM images of expansive soil (a) at room temperature $\left(20^{\circ} \mathrm{C}\right)$ and heated at (b) $60^{\circ} \mathrm{C},(\mathrm{c}) 100^{\circ} \mathrm{C}$, and (d) $140^{\circ} \mathrm{C}$.

easy to gather together. The increasing tendency of particle size is consistent with the values measured by laser particle size analyzer as shown in Figure 4(b).

Different microstructures result from different physical and chemical progresses. With the influence of heating at 60 and $100^{\circ} \mathrm{C}$, expansive soil lose the majority of its free water and part of physically absorbed water. So Figures $5(\mathrm{~b})-5(\mathrm{c})$ present small particles and a high porosity, corresponding to a low density as shown in Figure $4(\mathrm{~b})$. When heated at $140^{\circ} \mathrm{C}$, with the decomposition of phases like carbonate terrane, expansive soil has lost almost all the physically absorbed water and part of the chemically bound water. So it can have larger particle and higher porosity (also higher density) than when heated at $60^{\circ} \mathrm{C}$ (Figure 5(d)).

4.4. Hydraulic Behaviors and Shearing Resistance. As one type of unsaturated soil, the existence of gaseous phase, water, and soil skeleton in expansive soil is the main reason leading to the complex properties. Thus, the research on the existing form of gas phase and water phase and the migration law of gas and water under stress is indispensable to know its physical properties [20, 22, 23]. And the hydraulic behaviors and strength performance play fundamental role in the pollution prevention, modification, and engineering application of expansive soil. Therefore, these relevant researches have been carried out and the test results are shown in Figure 6.

Both unheated expansive soil $\left(20^{\circ} \mathrm{C}\right)$ and samples heated at $100^{\circ} \mathrm{C}$ for $6 \mathrm{~h}$ belong to alkaline engineering materials. The hydraulic behaviors of expansive soil would critically influence the spread of harmful substances in underground water and further lead to serious pollution of the surrounding soil, air, and groundwater. Therefore, a deep recognition of the hydrodynamic characteristics of expansive soil is necessary for the pollution prevention of underground water. The measured hydraulic characteristics can be illustrated by soil-water characteristic curve (SWCC) and hydraulic conductivity characteristics curve (HCF), which are shown in Figure 6(a).

The SWCC curves indicate that, with the same change of water content, the change of matrix suction of unheated 


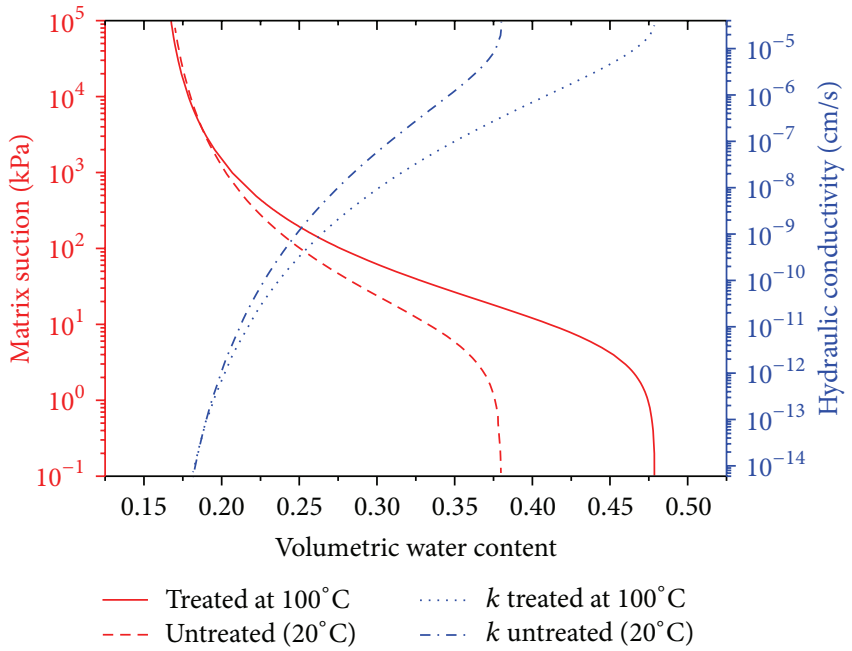

(a)

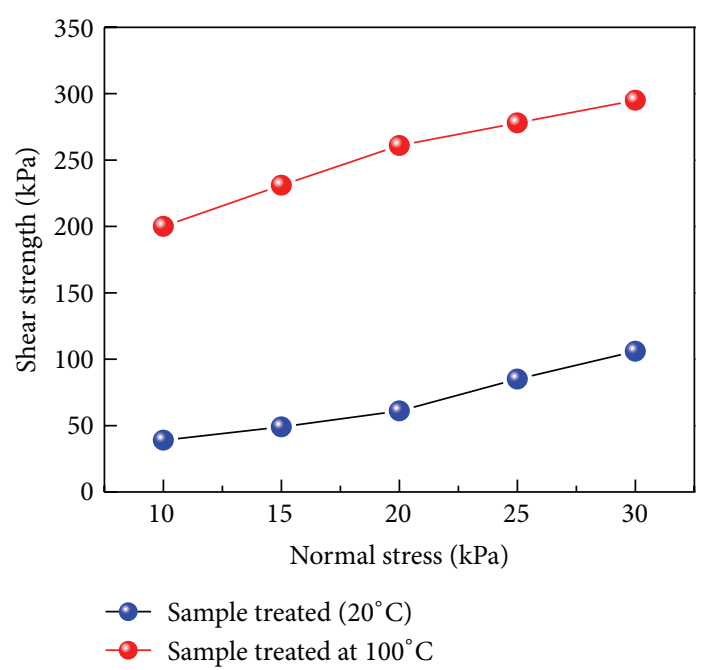

(b)

FIgURE 6: (a) The hydraulic characteristics of unheated $\left(20^{\circ} \mathrm{C}\right)$ and heated $\left(100^{\circ} \mathrm{C}\right)$ expansive soil. (b) Bond strength as the functions of heated temperature.

expansive soil (matrix suction value is a function of several factors like free water, electric combination water, cement force, and electrochemical power) is greater than that of expansive soil heated at $100^{\circ} \mathrm{C}$. This means that the water sensitivity of unheated expansive soil is greater than heated ones. As a consequence, under the same natural conditions, the stability of expansive soil after heat treatment is lower than that of unheated expansive soil. On the other hand, with the same water content, the hydraulic conductivity of the heated sample is better. It indicates that the liquid pollutants in expansive soil under high temperature are easier to filtrate and diffuse into the underground water and the surrounding environment.

The measurement shows that the strength of heated expansive soil is far higher than that of unheated soil. Then the direct shear tests were carried out for the purpose of further understanding the strength performance of the expansive soil under different temperature conditions. The testing results are shown in Figure 6(b).

The curves in Figure 6(b) indicate that, under the same experimental conditions, expansive soil heated at $100^{\circ} \mathrm{C}$ for $6 \mathrm{~h}$ has significantly high intensity. This is the same with the conclusion obtained in the sites. The bond strength of the two samples can be calculated through extending the strength envelope curve towards the left to the longitudinal axis of the coordinate system. The bond strength of heated expansive soil, $178 \mathrm{kPa}$, is significantly greater than that of unheated samples which is $26.3 \mathrm{kPa}$. In addition, it can be known that the angles of internal friction of the two materials are almost the same from the fact that two shear strength envelope curves are roughly parallel. These phenomena illustrate that the main reason why the strength of heated expansive soil is substantially higher is that it comes from the increase of bond strength.

\section{Conclusion}

In this project, the mineral and chemical composition and several essential physical parameters of unheated expansive soil samples taken from the western outskirts of Hanzhong of Shanxi Province, China, are tested and given out. Moreover, along with the change of temperature from $20^{\circ} \mathrm{C}$ to $140^{\circ} \mathrm{C}$, free water, physical absorbed water, and chemically bound water are lost in sequence. The mean particle diameter undertakes a sharp increase and the SEM shows that the microstructure becomes larger and more porous due to the decomposition of phases like carbonate terrane. The hydraulic behaviors and strength performance of unheated samples and the one heated at $100^{\circ} \mathrm{C}$ are also given out to demonstrate the mechanical properties during the engineering application. All these researches play fundamental role in the pollution prevention, modification, and engineering application of expansive soil.

\section{Conflict of Interests}

The authors declare that there is no conflict of interests regarding the publication of this paper.

\section{Acknowledgment}

The authors wish to thank Yuchao Xia for providing thoughtful and critical comments on the paper. The funding for this research is provided by the National Natural Science Foundation of China (Grant no. 41172261) which is greatly appreciated.

\section{References}

[1] J. K. Mitchell, Fundamentals of Soil Behavior, John Wiley \& Sons, New York, NY, USA, 1993. 
[2] J. R. Philip and D. A. de Vries, "Moisture movement in porous aterials under temperature gradients," Transactions, American Geophysical Union, vol. 38, no. 2, pp. 222-232, 1957.

[3] A. E. Dif and W. F. Bluemel, "Expansive soils under cyclic drying and wetting," Geotechnical Testing Journal, vol. 14, no. 1, pp. 96$102,1991$.

[4] H.-Z. Yu, X.-Q. Li, and J.-W. Yao, "Experimental study and analysis of expansive soil improved with chemical medicine," Rock and Soil Mechanics, vol. 27, no. 11, pp. 1941-1944, 2006.

[5] N. R. Morgenstem and J. S. Tchalenko, "Microscopic structure in kaolin subjected to direct shear," Geotechnique, vol. 17, no. 4, pp. 309-328, 1967.

[6] Q. Yang, H. Zhang, and M. Luan, "Testing study on shear strength of unsaturated expansive soils," Chinese Journal of Rock Mechanics and Engineering, vol. 23, no. 3, pp. 420-425, 2004.

[7] S.-B. Dai, J. Huang, and L. Xia, "Analysis of mineral composition and chemical components of expansive soil in North Hubei," Rock and Soil Mechanics, vol. 26, supplement 1, pp. 296-299, 2005.

[8] A. A. Al-Rawas, A. W. Hago, and H. Al-Sarmi, "Effect of lime, cement and Sarooj (artificial pozzolan) on the swelling potential of an expansive soil from Oman," Building and Environment, vol. 40, no. 5, pp. 681-687, 2005.

[9] B. R. Phani Kumar and R. S. Sharma, "Effect of fly ash on engineering properties of expansive soils," Journal of Geotechnical and Geoenvironmental Engineering, vol. 130, no. 7, pp. 764-767, 2004.

[10] Y. Xie, Z.-H. Chen, and G. Li, "Research of thermal effects on shear strength and deformation characteristics of unsaturated bentonite soils," Chinese Journal of Geotechnical Engineering, vol. 27, no. 9, pp. 1082-1085, 2005.

[11] A. A. Basma, A. S. Al-Homoud, A. I. Husein Malkawi, and M. A. Al-Bashabsheh, "Swelling-shrinkage behavior of natural expansive clays," Applied Clay Science, vol. 11, no. 2-4, pp. 211227, 1996.

[12] Z.-H. Chen, Y. Xie, S.-G. Sun, X.-W. Fang, and G. Li, “Temperature controlled triaxial apparatus for soils and its application," Chinese Journal of Geotechnical Engineering, vol. 27, no. 8, pp. 928-933, 2005.

[13] S. M. Rao and P. Shivananda, "Role of curing temperature in progress of lime-soil reactions," Geotechnical and Geological Engineering, vol. 23, no. 1, pp. 79-85, 2005.

[14] K. Harishkumar and K. Muthukkumaran, "Study on swelling soil behaviour and its improvements," International Journal of Earth Sciences and Engineering, vol. 4, no. 6, pp. 19-25, 2011.

[15] X.-W. Li, L.-W. Kong, A.-G. Guo, and Y. Zhang, "Strength characteristics of expansive soil considering effect of hydrous state," Rock and Soil Mechanics, vol. 29, no. 12, pp. 3193-3198, 2008.

[16] Y. Xie, Z.-H. Chen, and G. Li, "Thermo-nonlinear model for unsaturated expansive soils," Rock and Soil Mechanics, vol. 28, no. 9, pp. 1937-1942, 2007.

[17] D. de Bruyn and J.-F. Thimus, "The influence of temperature on mechanical characteristics of boom clay: the results of an initial laboratory programme," Engineering Geology, vol. 41, no. 1-4, pp. 117-126, 1996.

[18] H. Xiao, K. Teng, H. Xu et al., "Experimental study on deformation of nanning expansive soil consodidation and creep coupling," Journal of Hunan University of Technology, vol. 23, no. 5, pp. 1-6, 2009.
[19] X.-D. Ou, H. Wu, and D. Zhou, "Comparative study on thermodynamics characteristics of red clay and expansive soils in Guangxi," Rock and Soil Mechanics, vol. 26, no. 7, pp. 1068-1072, 2005.

[20] C. Bao, "Behavior of unsaturated soil and stability of expansive soil slope," Chinese Journal of Geotechnical Engineering, vol. 26, no. 1, pp. 1-15, 2004.

[21] T. Mao and L. Xia, "Experimental research on microstructure of expansive soil in north of Hubei province," Journal of Huazhong University of Science and Technology Urban Science, vol. 27, no. 2, pp. 48-52, 2010.

[22] A. T. Corey, "Meaeurement of water and air pemeability in unsaturated soil," Proceedings of the Soil Science Society of America, no. 21, pp. 7-10, 1957.

[23] L. Zhan, Field and Laboratory Study of an Unsaturated Expansive Soil Associated with Rain-Induced Slope Instability, The Hong Kong University of Science and Technology (HKUST), Hong Kong, 2003. 

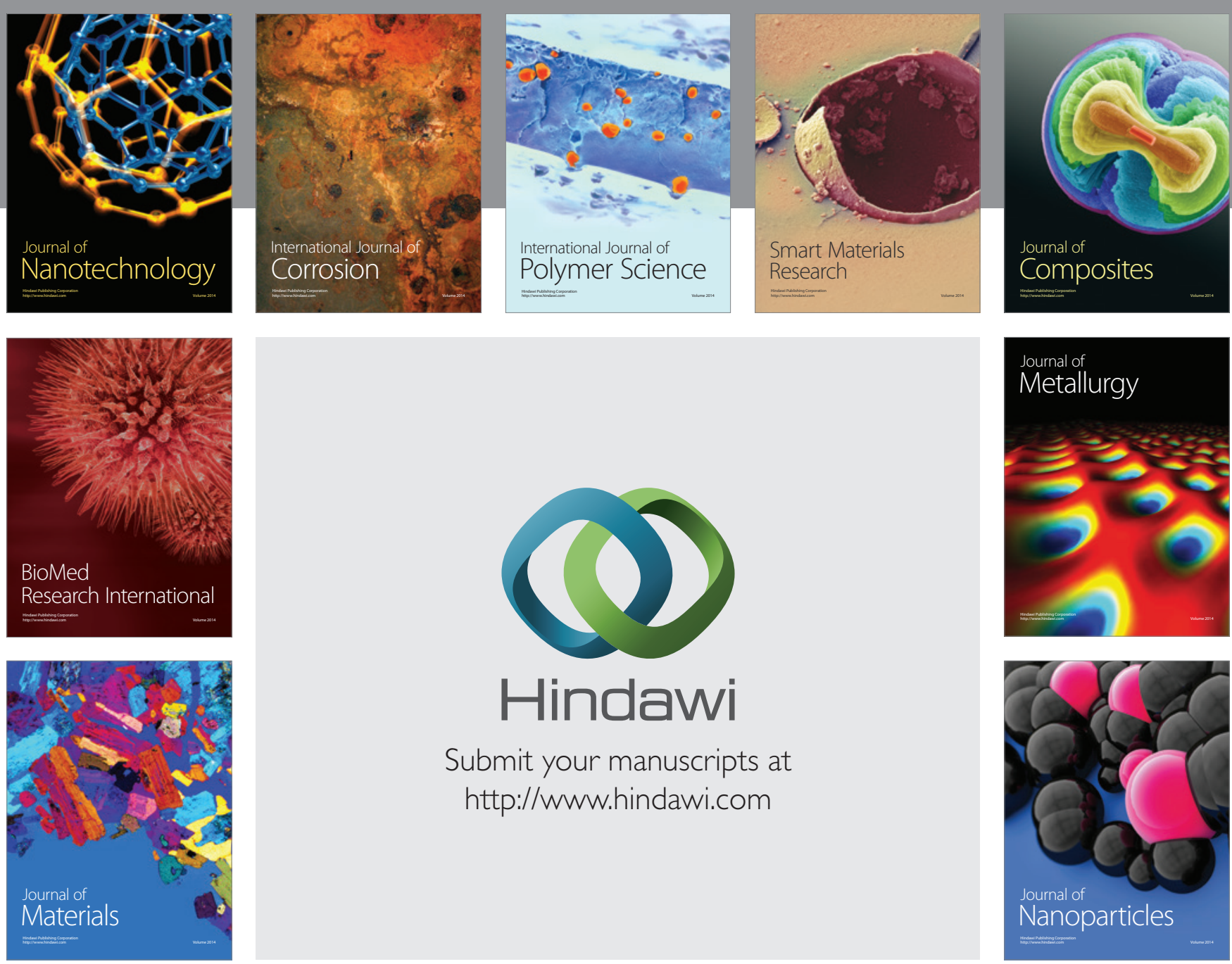

Submit your manuscripts at http://www.hindawi.com
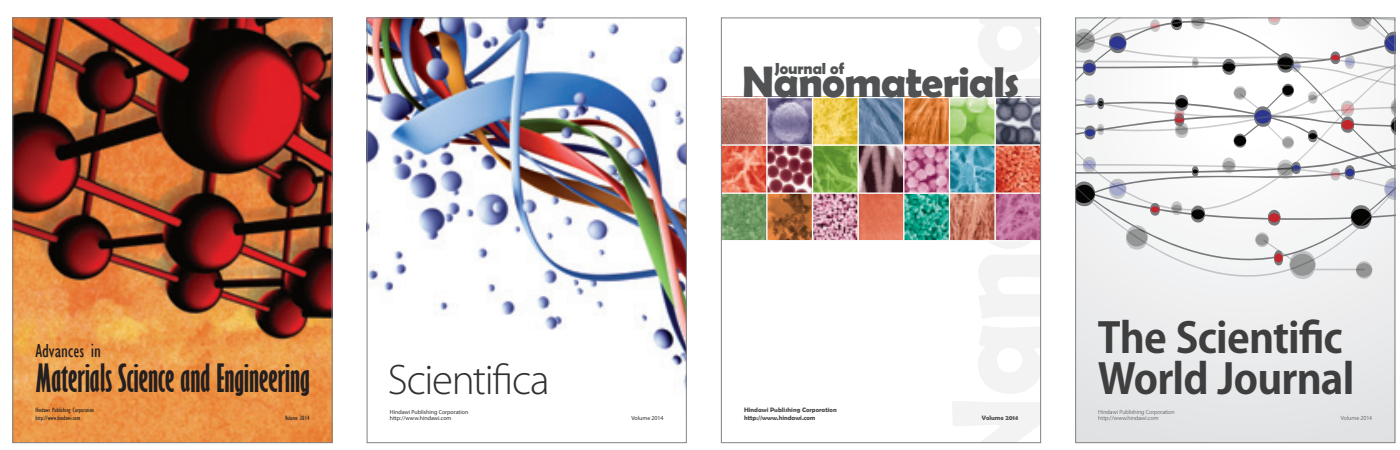

\section{The Scientific World Journal}
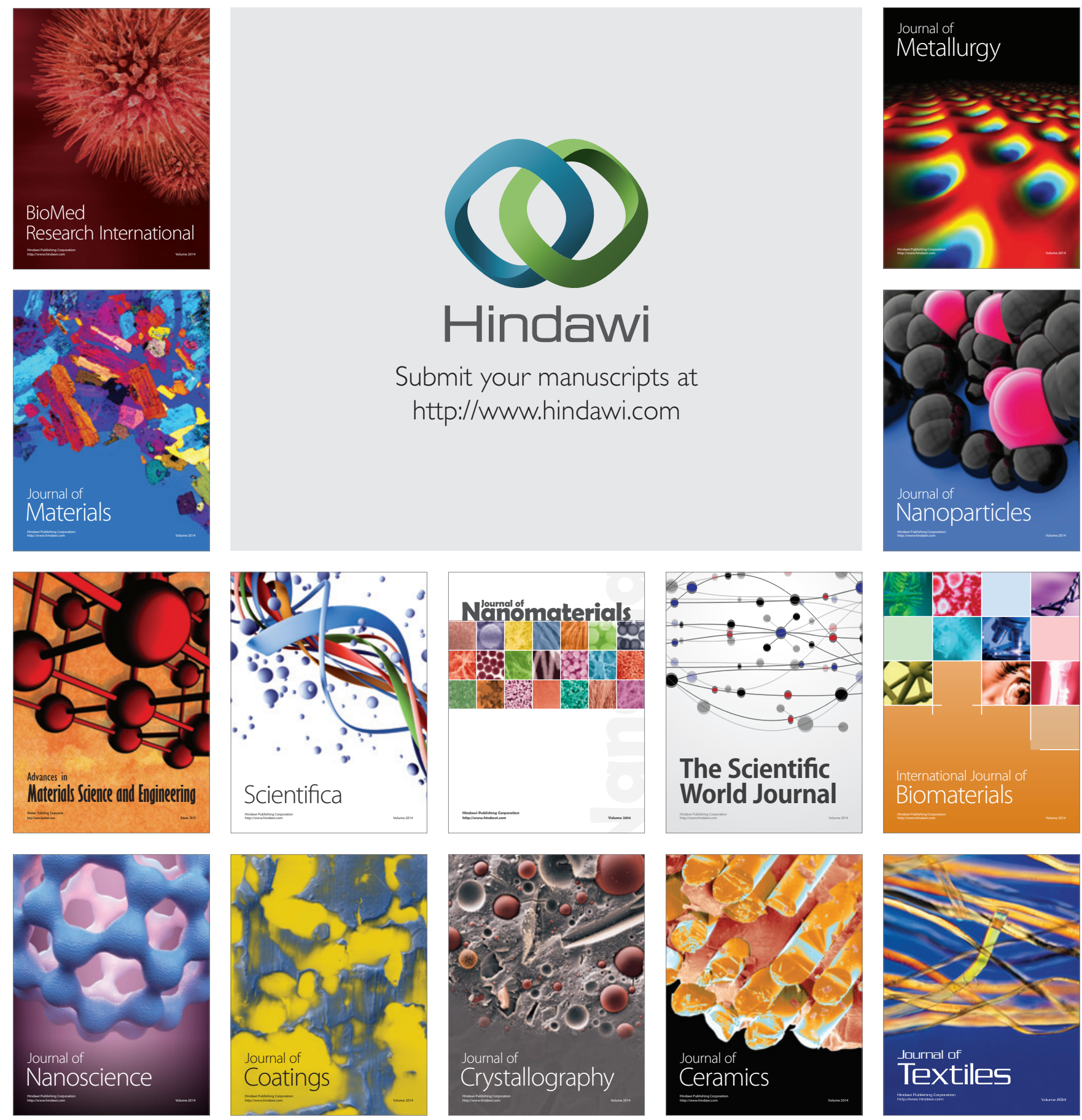